\title{
Study of Temperature Coefficients for Parameters of Photovoltaic Cells
}

\author{
Daniel Tudor Cotfas $(\mathbb{D}$, Petru Adrian Cotfas $(\mathbb{D}$, and Octavian Mihai Machidon $(\mathbb{D}$
}

Electronics and Computers Department, Transilvania University of Brasov, Brasov, Romania

Correspondence should be addressed to Daniel Tudor Cotfas; dtcotfas@unitbv.ro

Received 11 September 2017; Revised 19 November 2017; Accepted 22 January 2018; Published 1 April 2018

Academic Editor: Leonardo Sandrolini

Copyright ( 2018 Daniel Tudor Cotfas et al. This is an open access article distributed under the Creative Commons Attribution License, which permits unrestricted use, distribution, and reproduction in any medium, provided the original work is properly cited.

\begin{abstract}
The temperature is one of the most important factors which affect the performance of the photovoltaic cells and panels along with the irradiance. The current voltage characteristics, $I-V$, are measured at different temperatures from $25^{\circ} \mathrm{C}$ to $87^{\circ} \mathrm{C}$ and at different illumination levels from 400 to $1000 \mathrm{~W} / \mathrm{m}^{2}$, because there are locations where the upper limit of the photovoltaic cells working temperature exceeds $80^{\circ} \mathrm{C}$. This study reports the influence of the temperature and the irradiance on the important parameters of four commercial photovoltaic cell types: monocrystalline silicon- $\mathrm{mSi}$, polycrystalline silicon-pSi, amorphous silicon-aSi, and multijunction InGaP/InGaAs/Ge (Emcore). The absolute and normalized temperature coefficients are determined and compared with their values from the related literature. The variation of the absolute temperature coefficient function of the irradiance and its significance to accurately determine the important parameters of the photovoltaic cells are also presented. The analysis is made on different types of photovoltaics cells in order to understand the effects of technology on temperature coefficients. The comparison between the open-circuit voltage and short-circuit current was also performed, calculated using the temperature coefficients, determined, and measured, in various conditions. The measurements are realized using the SolarLab system, and the photovoltaic cell parameters are determined and compared using the LabVIEW software created for SolarLab system.
\end{abstract}

\section{Introduction}

An increasing number of countries have introduced renewable energy policies to reduce the greenhouse gas emissions and to avoid an energetic crisis created by the exhaustion of the fossil fuels. Most of them have fixed targets for using different types of renewable energy, and for this, they offer financial support [1]. The ways to improve the renewable energy domain are to develop hybrid renewable energy systems $[2,3]$, to solve the problems created when the renewable energy is inserted in the electrical power system [3], to achieve a very good integration of the renewable energy in buildings [4], to solve the storage problem, and to increase the efficiency of the existing ones.

The important role that the photovoltaic technology plays in the renewable energy domain is demonstrated by the dynamics, by the photovoltaic capacity installed worldwide (which is over $40 \mathrm{GW}$ each year over the last years), and by the growth in the number of jobs created, which is over 2.8 million and represents $30 \%$ from the total new jobs created in the renewable energy domain [1].

Due to the major interest for photovoltaic technology, the researchers have developed various types of photovoltaic cells, such as multijunction, perovskite, and quantum well [5-9]. Although these types of photovoltaic cells are very promising, the monocrystalline, polycrystalline, and the amorphous silicon photovoltaic cells and panels are still more widely used in terrestrial applications. The multijunction photovoltaic cells are highly efficient, but because of their rather high price, they are generally used in space applications and in concentrated light applications.

The photovoltaic cells and panels can be characterized using their important dc parameters: the photogenerated current, $I_{\mathrm{ph}}$; the short-circuit current, $I_{\mathrm{sc}}$; the open-circuit voltage, $V_{\mathrm{oc}}$; the maximum power, $P_{\max }$; the fill factor, FF; the efficiency, $\eta$; the series resistance, $R_{s}$; the shunt resistance, 
$R_{\mathrm{sh}}$; the ideality factor of diode, $m$; and the reverse saturation current, $I_{\mathrm{o}}[10]$. Using the $I-V$ characteristic, the equivalent circuit and one or more of the methods developed by researchers in the last 40 years, [10], the important parameters of the photovoltaic cells can be determined.

All the photovoltaic cell parameters are influenced by the temperature variation. If the temperature of the photovoltaic cells increases, most of them being influenced negatively-they decrease. The others increase with temperature, such as the short-circuit current, which slightly increases, and the reverse saturation current which increases exponentially [11-14].

The temperature of the photovoltaic cells in most of the locations varies from $0^{\circ} \mathrm{C}$ to $60^{\circ} \mathrm{C}$. There are locations where the lower limit of the working temperature can be below $-20^{\circ} \mathrm{C}$ and the upper limit can be over $80^{\circ} \mathrm{C}$ in semiarid areas [15]. These limits can be exceeded in other applications such as the spatial applications and concentrated light applications or extreme locations $[16,17]$.

The behavior of the photovoltaic cell parameter function of the temperature is very well described by the temperature coefficients [11-21]. The temperature coefficients, TC, can be absolute and normalized as in the following $[13,18,21]$ :

$$
\begin{aligned}
\mathrm{TC}_{\mathrm{a}}(p) & =\frac{d p}{d T}, \\
\mathrm{TC}_{\mathrm{n}}(p) & =\left.\frac{1}{p} \frac{d p}{d T}\right|_{T=25^{\circ} \mathrm{C}},
\end{aligned}
$$

where $p$ represents the parameter of the photovoltaic cell and $T$ is the temperature.

The dependence of the photovoltaic cell parameter function of the temperature is approximately linear [21], and thus, the temperature coefficients of the parameters can be determined experimentally using the linear regression method [22]. The mechanisms which influence the performance of the photovoltaic cell can be better studied if the normalized temperature coefficient of the $P_{\max }$ is considered as a sum of the normalized temperature coefficients of the $I_{\mathrm{sc}}$, $V_{\text {oc }}$, and FF $[12,21]$.

Four types of commercial photovoltaic cells are taken into consideration for this study: three from the silicon famil$\mathrm{y}$-the monocrystalline, polycrystalline, and the amorphous silicon photovoltaic cells-and one from the multijunction family-InGaP/InGaAs/Ge photovoltaic cell. The important parameters of these photovoltaic cells, like $I_{\mathrm{sc}}, V_{\mathrm{oc}}, P_{\max }$, $\mathrm{FF}, \eta, R_{\mathrm{s}}$, and $m$ were studied related to the temperature, which was varied from $25^{\circ} \mathrm{C}$ to $87^{\circ} \mathrm{C}$. The temperature coefficients of the photovoltaic cell parameters are determined and compared with the reference ones found in the related literature. The dependence of the temperature coefficients for $I_{\mathrm{sc}}, V_{\mathrm{oc}}, P_{\max }, \mathrm{FF}$, and $\eta$ upon the irradiance was also studied.

\section{Theoretical Considerations}

The $I-V$ characteristic and the equivalent circuit with the suitable mathematical model are important tools to study and to determine the parameters of the photovoltaic cells in

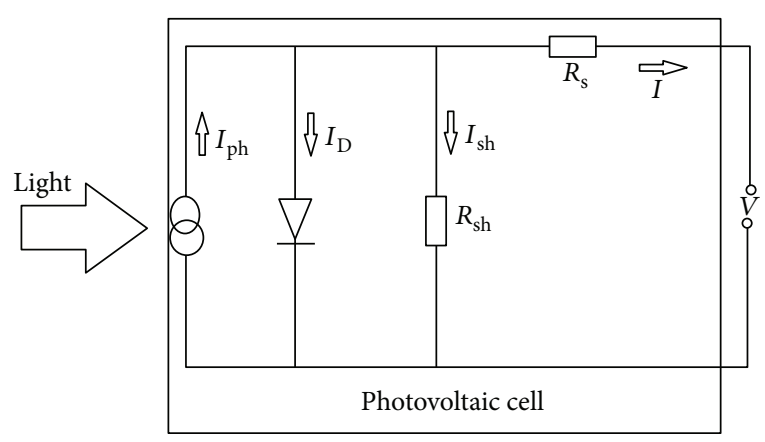

FIgURE 1: The equivalent circuit for one-diode model.

different conditions. There are three models: one-, two-, and three-diode model function of the electric current conduction mechanism from the photovoltaic cell as the diffusion mechanism, the generation-recombination mechanism, and the thermionic mechanism [10]. The generally accepted model is the one-diode model [10,23]. The equivalent circuit for this model can be seen in Figure 1, and the model is described mathematically by the following equation:

$$
I=I_{\mathrm{ph}}-I_{\mathrm{o}}\left(e^{\left(V+I R_{\mathrm{s}}\right) / V_{\mathrm{T}} m}-1\right)-\frac{V+I R_{\mathrm{s}}}{R_{\mathrm{sh}}},
$$

where $V_{\mathrm{T}}=k T / q$ is the thermal voltage, $T$ is the temperature, $k$ is the Boltzmann constant, and $q$ represents the elementary charge.

The generally used equivalent circuit and the model for analyzing the multijunction InGaP/InGaAs/Ge photovoltaic cell consist of three one-diode models, one for each junction, connected in series [24].

The open-circuit voltage can be obtained using (2) where $I=0$ and $I_{\mathrm{ph}} \approx I_{\mathrm{sc}}, m$ is equal to 1 , and the shunt resistance is considered very high. In this case, the last term of (2) tends towards zero and can be neglected. Deriving the equation obtained in function of the temperature, the absolute temperature coefficient of the open-circuit voltage is given by the following equation [13]:

$$
\frac{d V_{\mathrm{oc}}}{d T}=\frac{V_{\mathrm{oc}}}{T}+V_{\mathrm{T}}\left(\frac{1}{I_{\mathrm{sc}}} \frac{d I_{\mathrm{sc}}}{d T}-\frac{1}{I_{\mathrm{o}}} \frac{d I_{\mathrm{o}}}{d T}\right) .
$$

The reverse saturation current of the photovoltaic cell is a parameter strongly dependent on the temperature. This dependence is given by the following empirical equation which was simplified by Green [25]:

$$
I_{0}=A e^{\left(-\left(q E_{\mathrm{g}} / k T\right)\right)},
$$

where $A$ is a constant equal to $1.5 \times 10^{8} \mathrm{~mA} \mathrm{~cm}^{-2}$ and $E_{\mathrm{g}}$ represents the band gap energy.

The variation of the reverse saturation current function of the temperature [16] is given as follows:

$$
\frac{1}{I_{\mathrm{o}}} \frac{d I_{\mathrm{o}}}{d T}=-\frac{1}{V_{\mathrm{T}}}\left(-\frac{E_{\mathrm{g}}}{T}+\frac{d E_{\mathrm{g}}}{d T}\right) .
$$

The fill factor temperature coefficient can be calculated using the fill factor formula given by Green [25] or using 


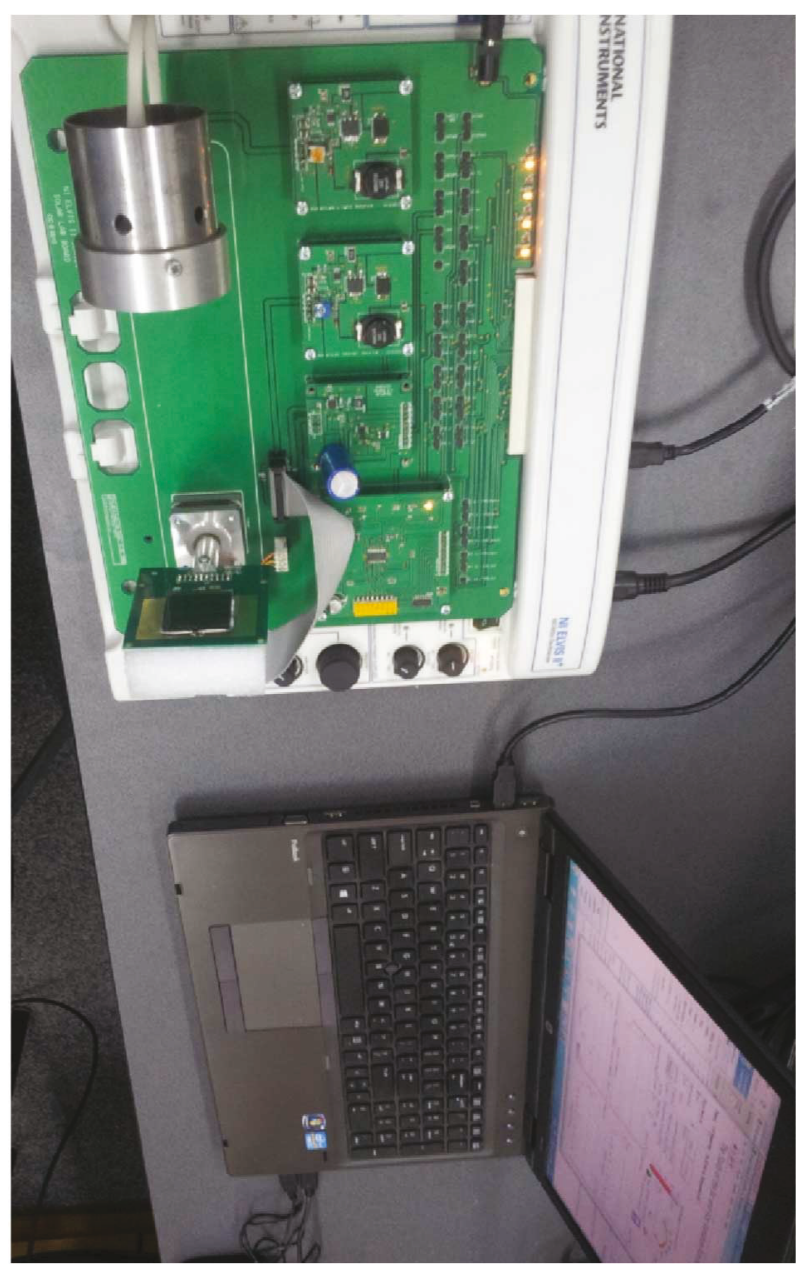

Figure 2: The SolarLab system used to characterize the photovoltaic cells.

the formula which takes into account the series resistance [12]. Using the Green formula, the absolute temperature coefficient is obtained as follows:

$$
\frac{\mathrm{dFF}}{d T}=\frac{\left(d V_{\mathrm{oc}} / d T\right)-\left(V_{\mathrm{oc}} / T\right)}{V_{\mathrm{oc}}+V_{\mathrm{T}}}\left(\frac{\left(V_{\mathrm{oc}} / V_{\mathrm{T}}\right)-0.28}{\left(V_{\mathrm{oc}} / V_{\mathrm{T}}\right)+0.72}-\mathrm{FF}\right) .
$$

The absolute temperature coefficient of the photovoltaic cell efficiency can be determined by linear fitting of the efficiency dependence on the temperature. The efficiency is calculated as follows:

$$
\eta=\frac{P_{\max }}{I_{\mathrm{t}} \times A}
$$

where $A$ represents the area of the photovoltaic cell and $I_{\mathrm{t}}$ is the irradiance.

The $V_{\mathrm{oc}}, I_{\mathrm{sc}}$, and $P_{\max }$ are parameters which can be determined very easily from the $I-V$ characteristic of the photovoltaic cell and also FF using (8). The normalized temperature coefficient of the reverse saturation current, $\mathrm{TC}_{\mathrm{n}}\left(I_{\mathrm{o}}\right)$, can be calculated, using (3), and the temperature coefficients, $\mathrm{TC}_{\mathrm{a}}\left(V_{\mathrm{oc}}\right)$ and $\mathrm{TC}_{\mathrm{n}}\left(I_{\mathrm{sc}}\right)$ can be determined experimentally. The advantage of this method is that it does not require the determination of $I_{0}$. Also, the absolute coefficient of the energy band gap, $\operatorname{TC}_{\mathrm{a}}\left(E_{\mathrm{g}}\right)$, can be determined using (5), $\mathrm{TC}_{\mathrm{n}}\left(I_{\mathrm{o}}\right)$ and the value of $E_{\mathrm{g}}$ at $25^{\circ} \mathrm{C}$ from the literature [26] without determination of the $E_{\mathrm{g}}$.

$$
\mathrm{FF}=\frac{P_{\max }}{I_{\mathrm{sc}} \times V_{\mathrm{oc}}}
$$

The influence magnitude of the series resistance and the ideality factor of diode can be found by the comparison of the results obtained for $\mathrm{TC}_{\mathrm{a}}(\mathrm{FF})$ using (6) and by linear regression of the dependency FF versus $T$ obtained experimentally.

\section{Experimental Set-Up}

Four types of commercial photovoltaic cells-monocrystalline silicon $3 \mathrm{~cm} / 3 \mathrm{~cm}$, polycrystalline silicon $2.7 \mathrm{~cm} / 1.3 \mathrm{~cm}$, amorphous silicon $3 \mathrm{~cm} / 3 \mathrm{~cm}$, and triple junction $\mathrm{InGaP} /$ InGaAs $/ G e 1 \mathrm{~cm} / 1 \mathrm{~cm}$-were measured function of temperature and irradiance and also analyzed and compared. The band gap energies of the InGaP/InGaAs/Ge photovoltaic cell junctions are $1.86 \mathrm{eV} / 1.40 \mathrm{eV} / 0.67 \mathrm{eV}$. For each type of photovoltaic cells, several ones were measured in order to choose a representative one.

The $I-V$ characteristics of the photovoltaic cells were measured using the SolarLab system developed by the authors [27] (see Figure 2).

The SolarLab system allows varying the temperature of the photovoltaic cells, and the $I-V$ characteristic is measured at constant temperature. The temperature was maintained constant using a PID (proportional-integral-derivative controller) algorithm which is implemented in the software which serves the system.

The system is covered with a black box to avoid the reflection or other light sources and to minimize the temperature variation of the photovoltaic cell under test.

The $I-V$ characteristics of the four photovoltaic cells are measured at different levels of illuminations from $400 \mathrm{~W} / \mathrm{m}^{2}$ to $1000 \mathrm{~W} / \mathrm{m}^{2}$, and for each level of illumination, the temperature of the photovoltaic cell was varied from $25^{\circ} \mathrm{C}$ to $87^{\circ} \mathrm{C}$.

The temperature of the photovoltaic cell and the irradiance are measured simultaneously with the $I-V$ characteristics. The accuracy of the temperature measurement is $\pm 0.5^{\circ} \mathrm{C}$, and the accuracy of the irradiance is $\pm 3 \mathrm{~W} / \mathrm{m}^{2}$.

The SolarLab software is used to control the measurement system, to make the data acquisition, and it has modules implemented to determine the important parameters of the photovoltaic cells using different methods developed by researchers $[10,27]$. The software application was created in the graphical programming language LabVIEW, and its interface is presented in Figure 3.

\section{Results}

The important parameters of the four photovoltaic cells are obtained using the SolarLab system, the $I-V$ characteristics, 


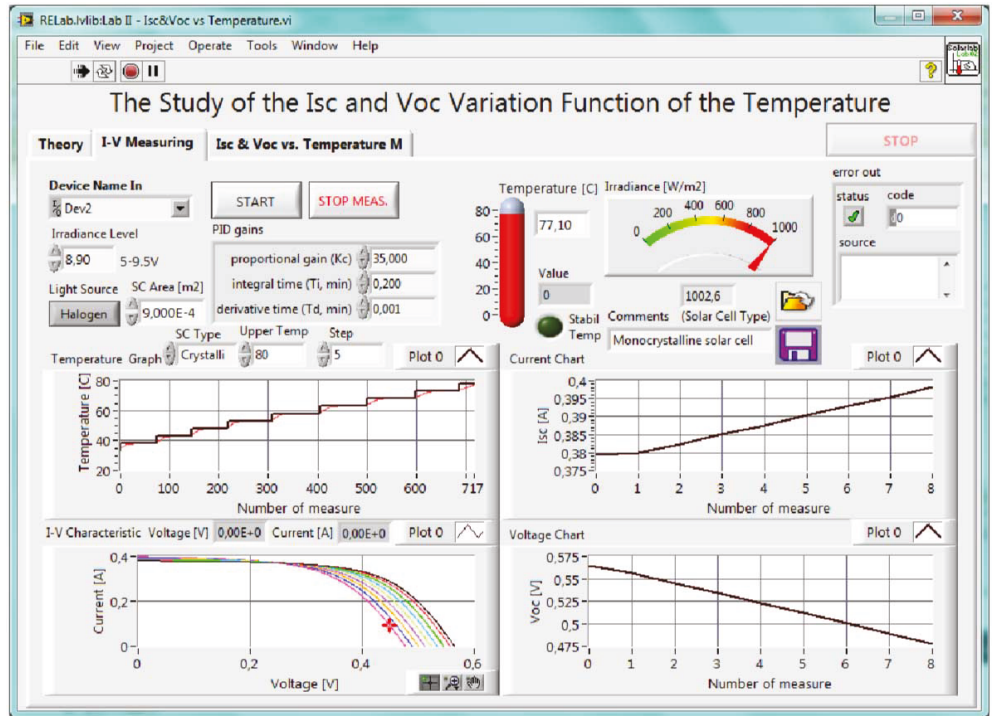

Figure 3: The interface of the SolarLab software.
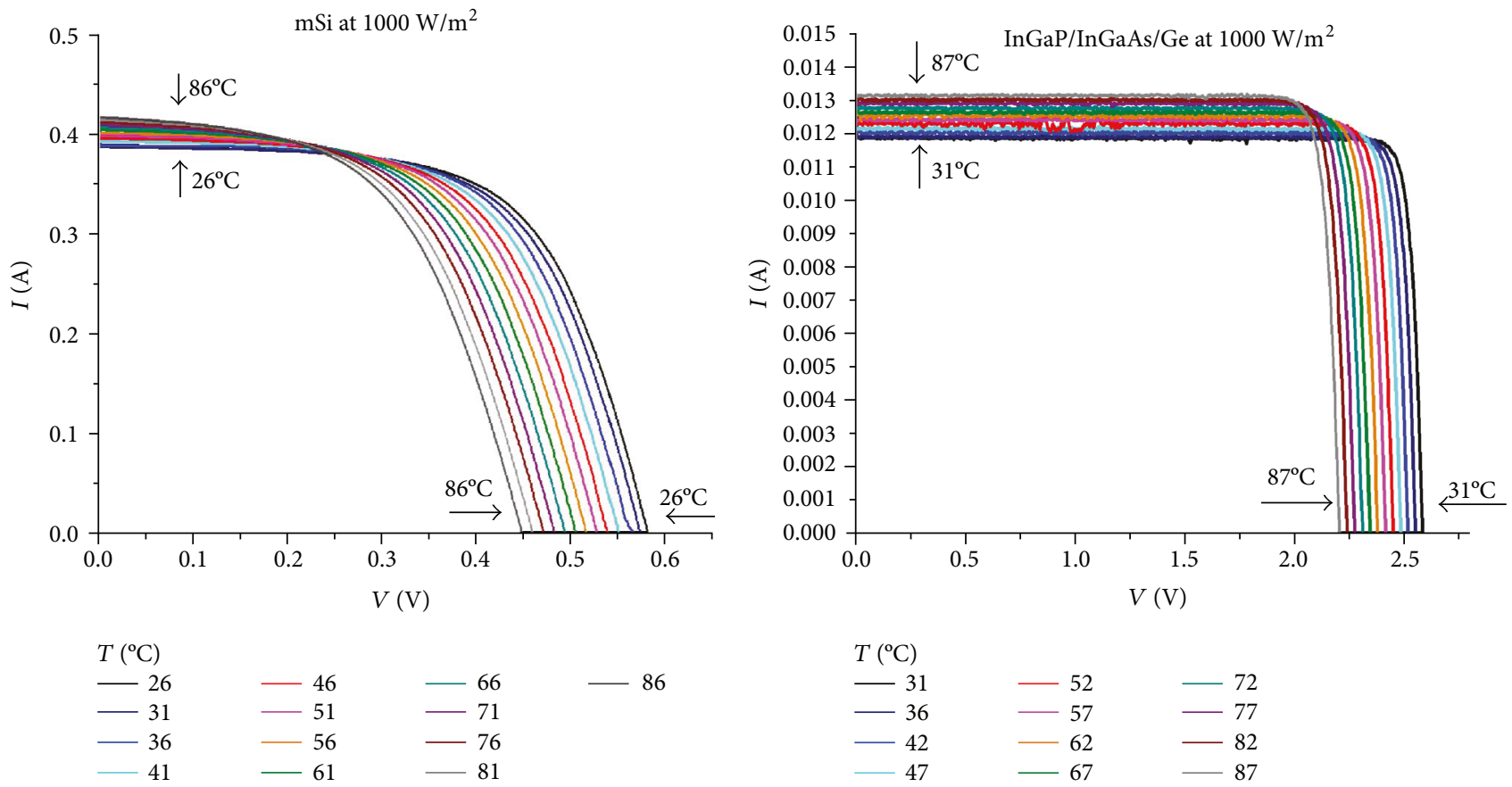

(a)

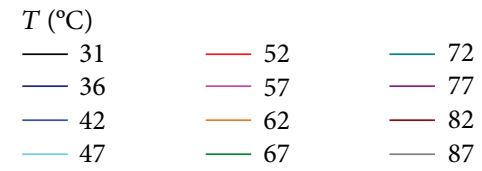

(b)

Figure 4: The $I-V$ characteristics versus temperature at $1000 \mathrm{~W} / \mathrm{m}^{2}$ irradiance for (a) $\mathrm{mSi}$ and (b) InGaP/InGaAs/Ge.

the-one diode model, and the analytical five-point method $[10,28]$ at different temperatures and different irradiance.

The $I-V$ characteristics measured under illumination at $1000 \mathrm{~W} / \mathrm{m}^{2}$ irradiance and at different temperatures, which varies from $26^{\circ} \mathrm{C}$ to $87^{\circ} \mathrm{C}$, are presented in Figure 4 (a) for $\mathrm{mSi}$ photovoltaic cell and in Figure 4(b) for InGaP/InGaAs/ Ge photovoltaic cell.

The open-circuit voltage is strongly affected by the temperature variation. The increase in temperature led to decreasing the value of the band gap energy (see (9)). The intrinsic carrier concentration, $n_{\mathrm{i}}$, increases because it depends inversely exponentially on the band gap energy [14]. Due to the proportionality of the $I_{\mathrm{o}}$ with $n_{\mathrm{i}}{ }^{2}$, the reverse saturation current increases with temperature. The increase is exponential (see (4)), leading to the decrease of the opencircuit voltage and the fill factor.

$$
E_{\mathrm{g}}(T)=E_{\mathrm{g}}(0)-\frac{\alpha T^{2}}{T+\beta},
$$

where $E_{\mathrm{g}}(0), \alpha$, and $\beta$ are material constants [14]. 

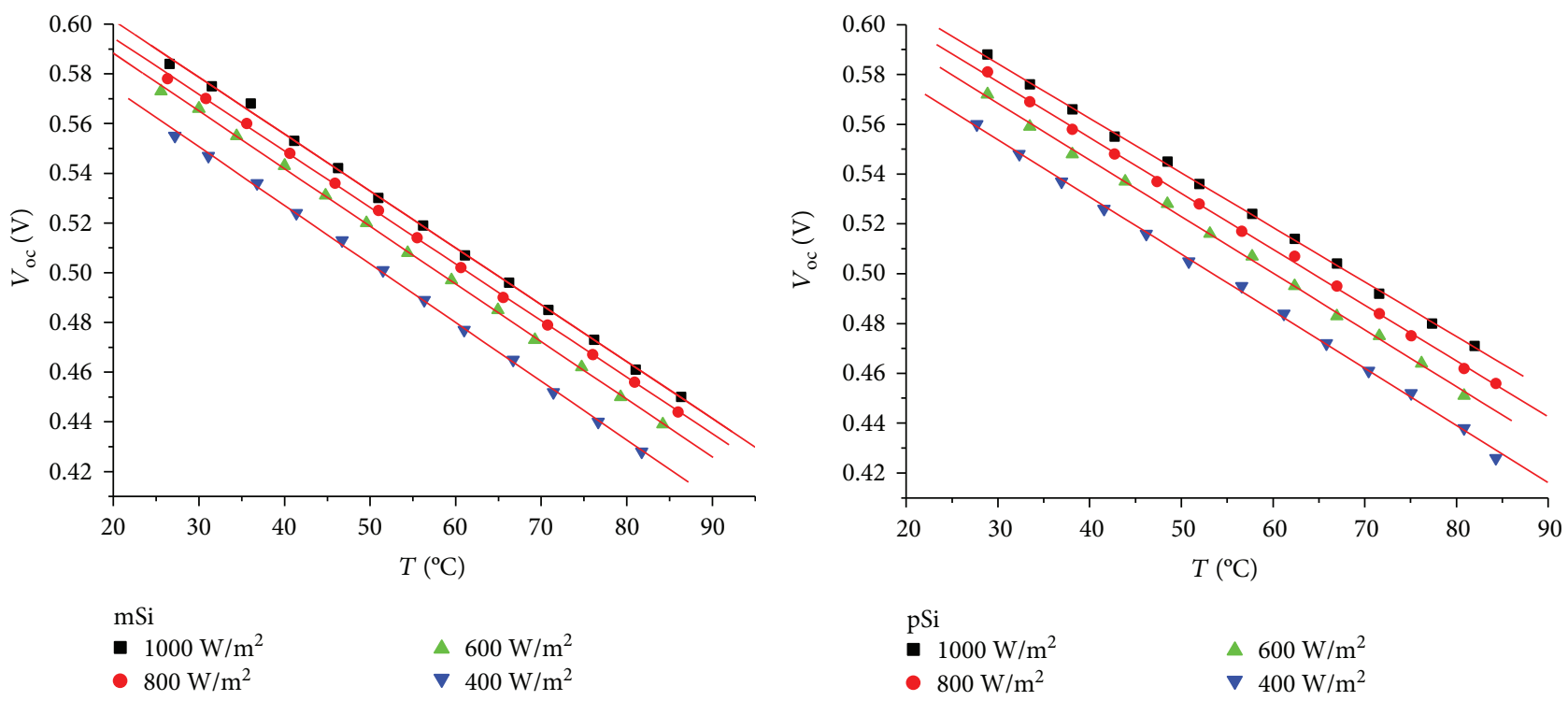

(a)
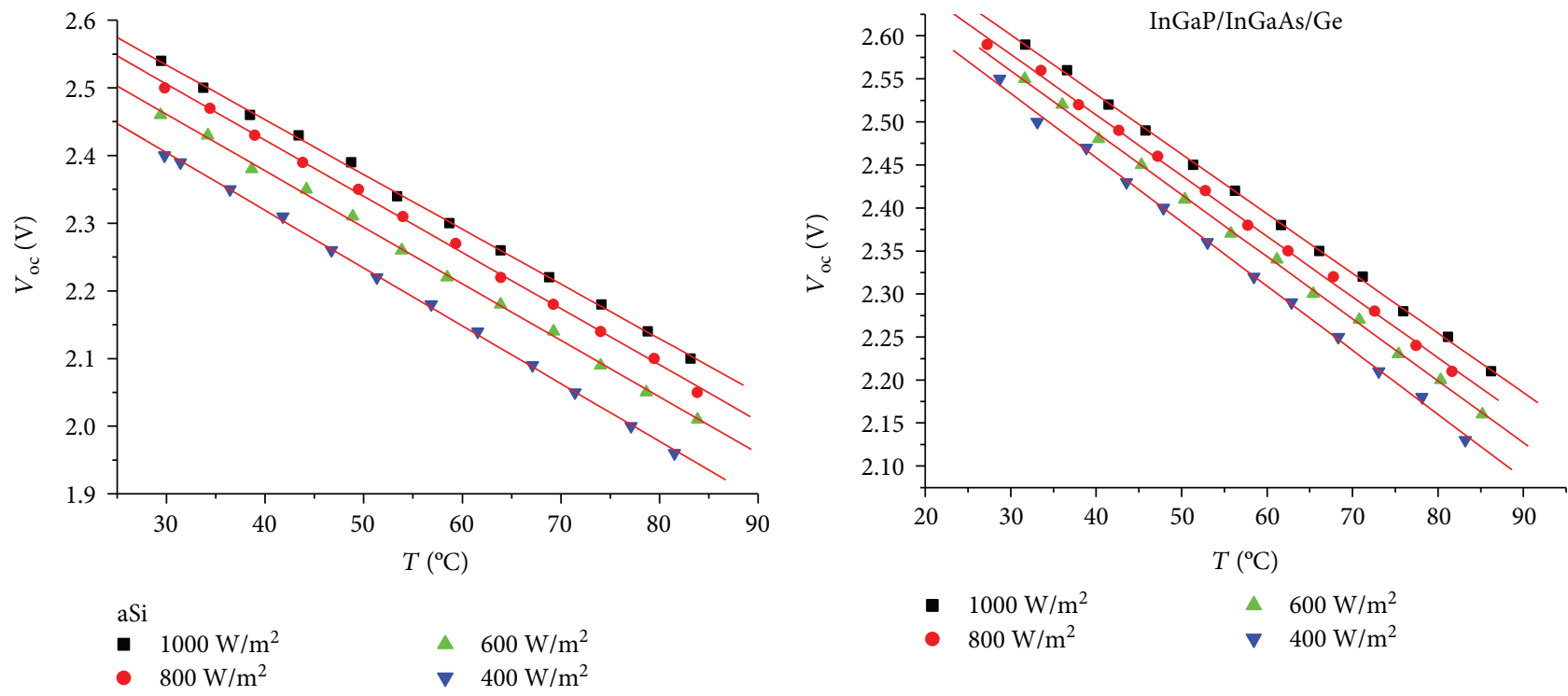

(c)

(d)

Figure 5: The open-circuit voltage versus temperature and irradiance for (a) mSi, (b) pSi, (c) aSi, and (d) InGaP/InGaAs/Ge. The lines represent the curve obtained by linear regression.

The behavior of the open-circuit voltage function of the temperature and irradiance is presented in Figure 5(a) for the monocrystalline photovoltaic cell, Figure $5(\mathrm{~b})$ for the polycrystalline photovoltaic cell, Figure 5(c) for the amorphous photovoltaic cell, and Figure 5(d) for the InGaP/ InGaAs/Ge photovoltaic cell.

The absolute temperature coefficients for the important parameters of the photovoltaic cells at different levels of illumination are presented in Table 1.

The short-circuit current slightly increases with temperature, as a consequence of the band gap energy reduction. In this case, the number of photons which have enough energy to create electron-hole pairs is higher. The behavior of the open-circuit voltage temperature coefficient and the short- circuit current temperature coefficient function of the irradiance is reverse.

The maximum power of the photovoltaic cells decreases when the temperature of the photovoltaic cells increases because the increase in the maximum current does not compensate for the decrease in the maximum voltage.

The values of the absolute and normalized temperature coefficients for different types of photovoltaic cells under $1000 \mathrm{~W} / \mathrm{m}^{2}$ illumination obtained in this paper (TI) and the ones from literature $[13,18,20,29,30]$ are presented in Table 2.

Analyzing the values of the temperature coefficients, a good matching can be observed for the $\mathrm{TC}_{\mathrm{a}}\left(V_{\mathrm{oc}}\right)$ and $\operatorname{TC}_{\mathrm{n}}\left(V_{\text {oc }}\right)$, but there are differences for the $\operatorname{TC}_{\mathrm{a}}\left(I_{\mathrm{sc}}\right)$. This 
TABLE 1: The absolute temperature coefficients for the important parameters of the photovoltaic cells.

\begin{tabular}{|c|c|c|c|c|c|}
\hline PV & $I_{\mathrm{T}}\left(\mathrm{W} / \mathrm{m}^{2}\right)$ & $d V_{\mathrm{oc}} / d T\left(\mathrm{mV}^{\circ} \mathrm{C}^{-1}\right)$ & $d I_{\mathrm{sc}} / d T\left(\mathrm{~mA}^{\circ} \mathrm{C}^{-1}\right)$ & $d P_{\max } / d T\left(\mathrm{~mW}^{\circ} \mathrm{C}^{-1}\right)$ & $\mathrm{dFF} / d T\left(\%{ }^{\circ} \mathrm{C}^{-1}\right)$ \\
\hline \multirow{4}{*}{$\mathrm{mSi}$} & 400 & -2.36 & 0.265 & -0.251 & -0.138 \\
\hline & 600 & -2.32 & 0.375 & -0.419 & -0.141 \\
\hline & 800 & -2.27 & 0.465 & -0.551 & -0.147 \\
\hline & 1000 & -2.24 & 0.537 & -0.691 & -0.162 \\
\hline \multirow{4}{*}{$\mathrm{pSi}$} & 400 & -2.29 & 0.108 & -0.07 & -0.122 \\
\hline & 600 & -2.27 & 0.147 & -0.103 & -0.130 \\
\hline & 800 & -2.24 & 0.191 & -0.128 & -0.139 \\
\hline & 1000 & -2.19 & 0.215 & -0.163 & -0.147 \\
\hline \multirow{4}{*}{$\mathrm{aSi}$} & 400 & -8.53 & 0.00727 & -0.0101 & -0.026 \\
\hline & 600 & -8.36 & 0.0106 & -0.0158 & -0.031 \\
\hline & 800 & -8.3 & 0.0151 & -0.0208 & -0.0411 \\
\hline & 1000 & -8.09 & 0.0187 & -0.0268 & -0.0487 \\
\hline \multirow{4}{*}{ InGaP/InGaAs/Ge } & 400 & -7.46 & 0.0125 & -0.016 & $-5.49 E-4$ \\
\hline & 600 & -7.21 & 0.0158 & -0.027 & $-5.6 E-4$ \\
\hline & 800 & -7.05 & 0.0194 & -0.032 & $-5.76 E-4$ \\
\hline & 1000 & -6.93 & 0.0253 & -0.040 & $-5.99 E-4$ \\
\hline
\end{tabular}

TABLE 2: Comparison between the temperature coefficients at $1000 \mathrm{~W} / \mathrm{m}^{2}$.

\begin{tabular}{|c|c|c|c|c|c|c|c|c|c|}
\hline $\begin{array}{l}\text { PV } \\
\text { cell }\end{array}$ & Ref. & $\begin{array}{c}d V_{\mathrm{oc}} / d T \\
\left(\mathrm{mV}^{\circ} \mathrm{C}^{-1}\right)\end{array}$ & $\begin{array}{c}\left(d V_{\mathrm{oc}} / d T\right) / V_{\mathrm{oc}} \\
\left(\mathrm{ppm} /{ }^{\circ} \mathrm{C}^{-1}\right)\end{array}$ & $\begin{array}{c}d I_{\mathrm{sc}} / d T \\
\left(\mathrm{~mA}^{\circ} \mathrm{C}^{-1}\right)\end{array}$ & $\begin{array}{c}\left(d I_{\mathrm{sc}} / d T\right) / I_{\mathrm{sc}} \\
\left(\mathrm{ppm} /{ }^{\circ} \mathrm{C}^{-1}\right)\end{array}$ & $\begin{array}{l}d P_{\max } / d T \\
\left(\mathrm{~mW}^{\circ} \mathrm{C}^{-1}\right)\end{array}$ & $\begin{array}{c}\left(d P_{\max } / d T\right) / P_{\max } \\
\left(\mathrm{ppm} /{ }^{\circ} \mathrm{C}^{-1}\right)\end{array}$ & $\begin{array}{l}\mathrm{dFF} / d T \\
\left(\%{ }^{\circ} \mathrm{C}^{-1}\right)\end{array}$ & $\begin{array}{c}(\mathrm{dFF} / d T) / \mathrm{FF} \\
\left(\mathrm{ppm} /{ }^{\circ} \mathrm{C}^{-1}\right)\end{array}$ \\
\hline \multirow{4}{*}{$\mathrm{mSi}$} & $\mathrm{TI}$ & -2.24 & -3835 & 0.537 & 138 & -0.691 & -4798 & -0.162 & -2189 \\
\hline & {$[16] c_{1}$} & -2.19 & - & 0.326 & - & - & - & - & - \\
\hline & {$[16] c_{2}$} & -2.36 & - & 0.401 & - & - & - & - & - \\
\hline & [18] & - & -3413 & - & 130 & - & -5035 & - & -1642 \\
\hline \multirow{2}{*}{$\mathrm{pSi}$} & TI & -2.19 & -3725 & 0.215 & 870 & -0.163 & -3713 & -0.147 & -2046 \\
\hline & [18] & - & -3675 & - & 675 & - & -4690 & - & -1732 \\
\hline \multirow{3}{*}{$\mathrm{aSi}$} & TI & -8.09 & - & 0.0187 & - & -0.0268 & - & -0.0487 & - \\
\hline & [29] a & -5.8 & - & 0.007 & - & -0.0138 & - & - & - \\
\hline & [29] b & -5.57 & - & 0.00788 & - & -0.0175 & - & - & - \\
\hline InGaP & $\mathrm{TI}$ & -6.93 & - & 0.0253 & - & -0.04 & - & $-5.99 E-4$ & - \\
\hline InGa & [30] & -6.2 & - & 0.005 & - & - & - & $-6 E-4$ & - \\
\hline $\mathrm{As} / \mathrm{Ge}$ & [20] & -5.6 & - & 0.0098 & - & -0.055 & - & $-6.3 E-4$ & - \\
\hline
\end{tabular}

difference influences the matching for the other temperature coefficients. The differences can be explained by the differences in fabrication process for the same type of photovoltaic cells and the difference between the measurement conditions, and a very important role is played by the illumination source. The differences for $\mathrm{TC}_{\mathrm{a}}\left(I_{\mathrm{sc}}\right)$ can be higher than $50 \%$ due to the spectral mismatch between the light sources used [18]. A very good matching is observed for the multijunction photovoltaic cell.

Analyzing the open-circuit voltage absolute temperature coefficient variation with the irradiance, for all types of the analyzed photovoltaic cells, a linear dependence is observed (see Figure 6(a)) and also, a linear dependency is obtained for the absolute temperature coefficient of the maximum power (see Figure 6(b)).
The positive slope of the linear dependency of the absolute temperature coefficient of the open-circuit voltage upon the irradiance shows a reduction in voltage drop if the temperature increases when the irradiance increases. The highest slope is obtained for the InGaP/InGaAS/Ge photovoltaic cell. The absolute temperature coefficient of the short-circuit current has the same behavior.

The negative slope of the linear dependency of the absolute temperature coefficient of the maximum power upon the irradiance shows a growth in power drop if the temperature increases when the irradiance increases. The best slope of photovoltaic cells' efficiency is obtained for the InGaP/ InGaAS/Ge photovoltaic cell. The amorphous silicon has a very good behavior, but it has a minor impact because the amorphous photovoltaic cell has the smallest maximum 


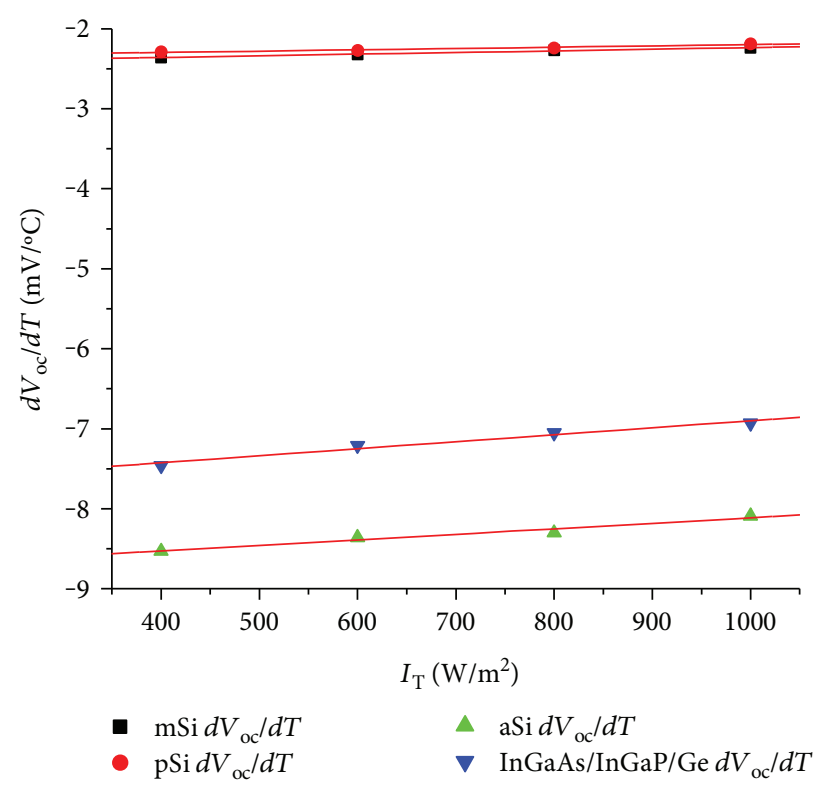

(a)

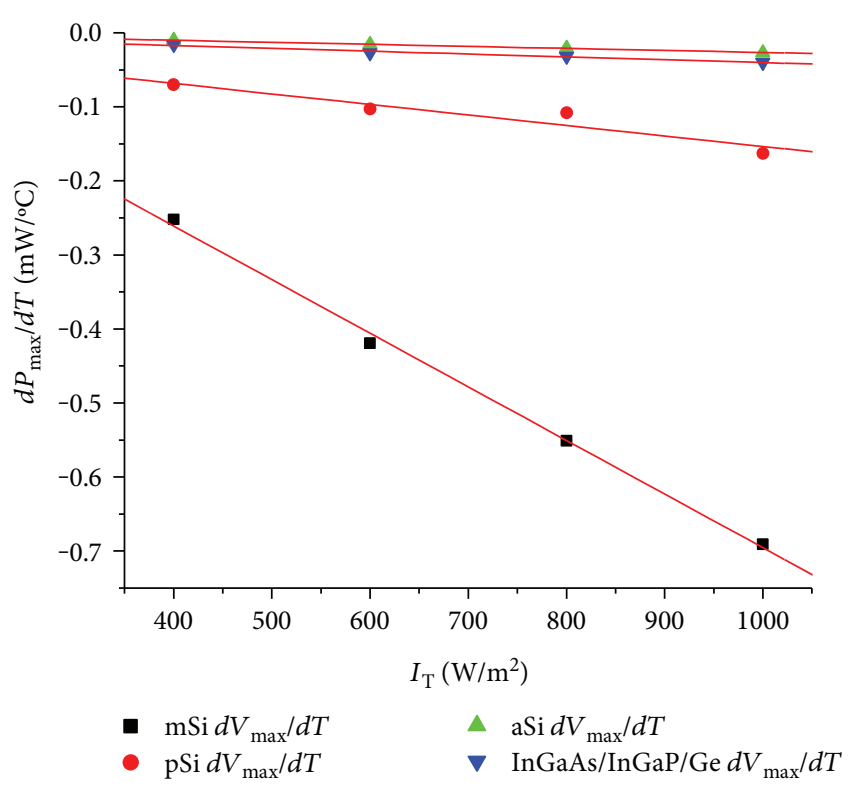

(b)

Figure 6: The dependency of the absolute temperature coefficient versus irradiance for all photovoltaic cells (a) for the open-circuit voltage and (b) for the maximum power.

power from all photovoltaic cells taken into account in this study. The similar results are obtained for the dependence $\mathrm{TC}_{\mathrm{a}}\left(V_{\mathrm{oc}}\right), \mathrm{TC}_{\mathrm{a}}\left(I_{\mathrm{sc}}\right)$, and $\mathrm{TC}_{\mathrm{a}}(\mathrm{FF})$ on the irradiance for two photovoltaic cells polycrystalline silicon and Elkem Solar Silicon by Tayyib et al. [31].

Prediction of the photovoltaic cell and panel output in real work conditions is very important for the final users. There are some models developed which can give the maximum power generated by the photovoltaic panels, the short-circuit current and the open-circuit voltage function of the irradiance and temperature using the values given for the manufacturers in the data sheet, determined at standard test conditions (STC)-global irradiance $1000 \mathrm{~W} / \mathrm{m}^{2}$, AM 1.5 , and panel temperature $25^{\circ} \mathrm{C}$ [32-36]. These models take into account the absolute temperature coefficients obtained at $1000 \mathrm{~W} / \mathrm{m}^{2}$ irradiance. Using the results obtained by the data analyzed, these models can be improved if the variation function of the irradiance is taken into account for the absolute temperature coefficients. The improved models to predict the maximum power generated by the photovoltaic panel at different irradiances and temperatures are given by (10), for the short-circuit current by (11) and for the opencircuit voltage by (12).

$$
P_{\max }=P_{\max (\mathrm{STC})} \frac{G}{1000}\left[1+\mathrm{TC}\left(P_{\max }, G\right)\left(T_{\mathrm{c}}-25\right)\right]
$$

where $P_{\max (\mathrm{STC})}$ is the maximum power at STC conditions, $G$ is the irradiance, $T_{c}$ represents the temperature of the photovoltaic cells, and TC $\left(P_{\max }, G\right)$ is the normalized temperature coefficient for the maximum power at irradiance $G$.

$$
I_{\mathrm{sc}}=I_{\mathrm{sc}(\mathrm{STC})} \frac{G}{1000}\left[1+\mathrm{TC}\left(I_{\mathrm{SC}}, G\right)\left(T_{\mathrm{c}}-25\right)\right]
$$

where $I_{\mathrm{SC}(\mathrm{STC})}$ is the short-circuit current at STC conditions and $\operatorname{TC}\left(I_{\mathrm{sc}}, G\right)$ is the normalized temperature coefficient for the short-circuit current at irradiance $G$.

$$
V_{\mathrm{oc}}=V_{\mathrm{oc}(\mathrm{STC})}\left[1+\mathrm{TC}\left(V_{\mathrm{OC}}, G\right)\left(T_{\mathrm{c}}-25\right)\right]+\mathrm{TC}(G) \ln \frac{G}{1000},
$$

where $V_{\text {OC(STC) }}$ is the open-circuit voltage at STC conditions, $\mathrm{TC}\left(V_{\mathrm{oc}}, G\right)$ is the normalized temperature coefficient for the open-circuit voltage at irradiance $G$ and $\operatorname{TC}(G)$ represents the temperature coefficient for the irradiance.

The $I-V$ characteristics for all photovoltaic cells under test were performed at temperature room which is $21^{\circ} \mathrm{C}$ and at $1000 \mathrm{~W} / \mathrm{m}^{2}$ irradiance (Figure 7). Using (11) and (12), the short-circuit current and the open-circuit voltage were calculated to compare the obtained results with measured ones. The results obtained for the representative photovoltaic cells are presented in Table 3 .

The difference between the measured and calculated value with (11) and (12) of the short-circuit current and the open-circuit voltage for all photovoltaic cells under test is under $0.1 \%$. Better results are obtained for $\mathrm{mSi}$ photovoltaic cell.

Two additional experiments were performed to verify the results obtained for the short-circuit current and the opencircuit voltage, one in lab conditions using a mSi photovoltaic cell with sizes $6 \mathrm{~cm} \times 8 \mathrm{~cm}$ (Figure 8 ). Both photovoltaic cells, $3 \mathrm{~cm} \times 3 \mathrm{~cm}$ and $6 \mathrm{~cm} \times 8 \mathrm{~cm}$, were cut from the mSi by the same lot. The halogen bulbs used to illuminate the photovoltaic cells are the same with halogen bulb of SolarLab. The other experiment was performed in natural sunlight conditions using $\mathrm{mSi}$ from the same lot with the cells tested with SolarLab, and the sizes are $12.5 \mathrm{~cm} \times 12.5 \mathrm{~cm}$ (Figure 9). 


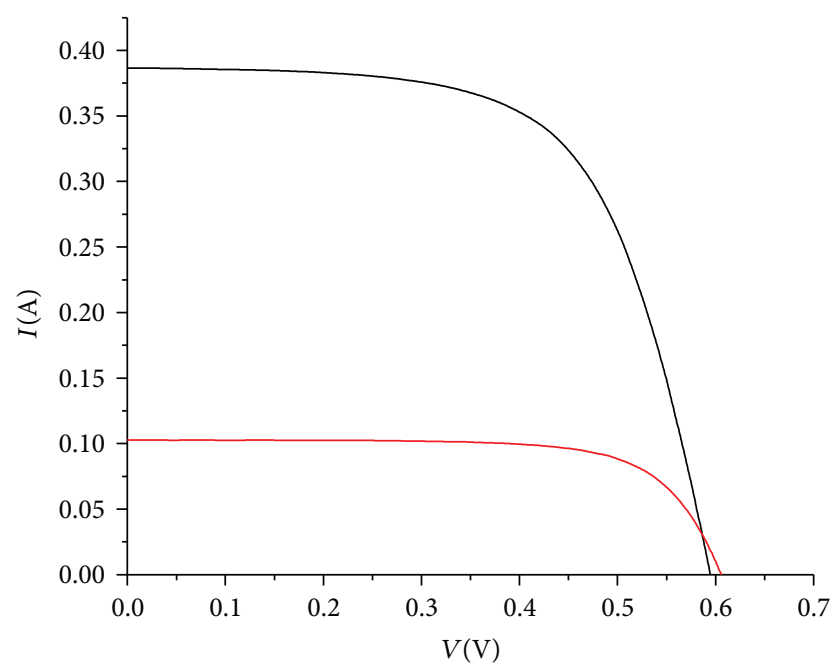

$1000 \mathrm{~W}, 21^{\circ} \mathrm{C}$

$\mathrm{mSi}$

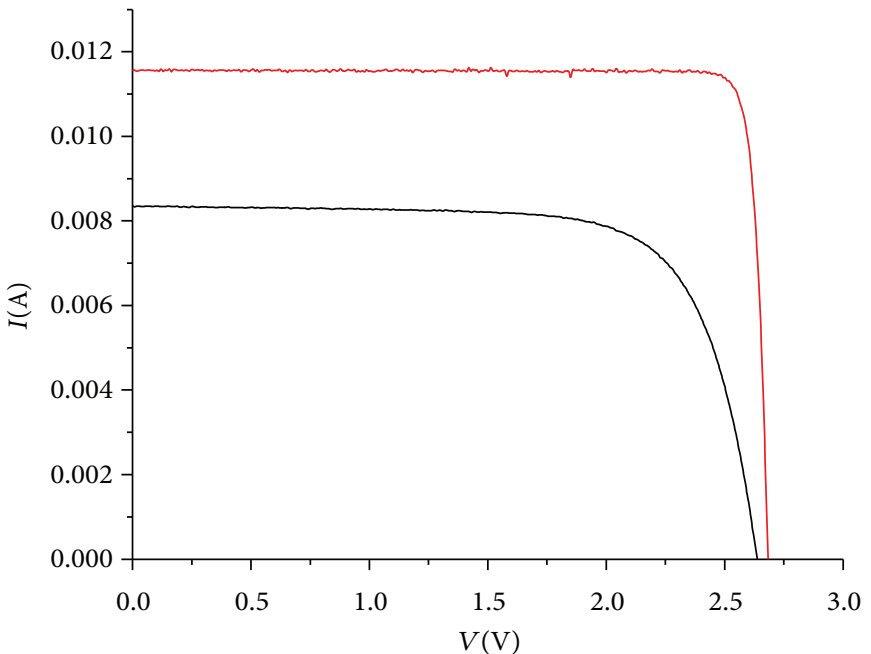

$1000 \mathrm{~W}, 21^{\circ} \mathrm{C}$

- $\mathrm{aSi}$

_ InGaP/InGaAs/Ge

(a)

(b)

Figure 7: The $I-V$ characteristics at $1000 \mathrm{~W} / \mathrm{m}^{2}$ and room temperature $21^{\circ} \mathrm{C}$ : (a) $\mathrm{mSi}$ and pSi; (b) aSi and InGaP/InGaAs/Ge.

TABLE 3: The calculated and measured values for $V_{\mathrm{oc}}$ and $I_{\mathrm{sc}}$.

\begin{tabular}{lcccccccc}
\hline & \multicolumn{2}{c}{$\mathrm{mSi}$} & \multicolumn{2}{c}{$\mathrm{pSi}$} & \multicolumn{2}{c}{$\mathrm{aSi}$} & \multicolumn{3}{c}{$\mathrm{InGaP} / \mathrm{InGaAs} / \mathrm{Ge}$} \\
& $V_{\mathrm{oc}}(\mathrm{V})$ & $I_{\mathrm{sc}}(\mathrm{A})$ & $V_{\mathrm{oc}}(\mathrm{V})$ & $I_{\mathrm{sc}}(\mathrm{A})$ & $V_{\mathrm{oc}}(\mathrm{V})$ & $I_{\mathrm{sc}}(\mathrm{A})$ & $V_{\mathrm{oc}}(\mathrm{V})$ & $I_{\mathrm{sc}}(\mathrm{A})$ \\
\hline Calculated & 0.59494 & 0.38664 & 0.60593 & 0.10273 & 2.6382 & 0.008346 & 2.6863 \\
Measured & 0.59483 & 0.38647 & 0.6058 & 0.102626 & 2.6396 & 0.008351 & 2.6878 & 0.01155 \\
\hline
\end{tabular}

The photovoltaic cells, in lab and outside, are cooled using Peltier module and water collector.

The $I-V$ characteristics were measured for two levels of irradiance $900 \mathrm{~W} / \mathrm{m}^{2}$ and $1000 \mathrm{~W} / \mathrm{m}^{2}$, and at $30^{\circ} \mathrm{C}$ temperature of the photovoltaic cells. The results obtained are presented in Table 4.

The difference between $V_{\text {oc }}$ calculated and measured is under $1.1 \mathrm{mV}$ which means a $0.5^{\circ} \mathrm{C}$ temperature difference in laboratory conditions and over $1^{\circ} \mathrm{C}$ in sunlight conditions. For $I_{\mathrm{sc}}$, this difference increases, almost doubling. The short-circuit current is very sensitive to the level of illumination. The irradiance was measured with three different sensors, one for each case. This can be explained by the increasing difference for $I_{s c}$. The difference between the results in laboratory and sunlight conditions can be due to the spectral difference between the light sources.

The extrapolation from the monocrystalline photovoltaic cells considered to a $15.6 \mathrm{~cm} \times 15.6 \mathrm{~cm}$ one is as follows: the open-circuit voltage temperature coefficient is the same, and the short-circuit current and maximum power temperature coefficients can be obtained by multiplying the determined temperature coefficient with the ratio between the areas of the two cells.

The maximum power generated by the photovoltaic cells is very important from the energy point of view. The decreasing percent in ${ }^{\circ} \mathrm{C}$ for the maximum power of the photovoltaic cells at $1000 \mathrm{~W} / \mathrm{m}^{2}$ is presented in Table 5 , where the result obtained for the photovoltaic panel is also presented. This percent slightly varies with the irradiance variation; for example, it varies from $0.38 \% /{ }^{\circ} \mathrm{C}$ at $1000 \mathrm{~W} / \mathrm{m}^{2}$ to $0.44 \% /{ }^{\circ} \mathrm{C}$ at $400 \mathrm{~W} / \mathrm{m}^{2}$ for polycrystalline photovoltaic cells. The best behavior is obtained for the multijunction photovoltaic cell.

The fill factor of all the photovoltaic cells considered in this study decreases with the temperature increase, and this dependence for $1000 \mathrm{~W} / \mathrm{m}^{2}$ is being presented in Figure 10 . The behavior of the fill factor function of the temperature is determined by the dependency of the open-circuit voltage, short-circuit current, and the maximum power on the temperature. By analyzing the FF dependency function of the temperature, it is observed that the FF temperature coefficient of the amorphous photovoltaic cell is the smallest and the FF temperature coefficient of the monocrystalline photovoltaic cell is the highest. This situation is the same for all illumination levels taken into consideration.

The FF temperature coefficient in absolute value decreases almost by half for the amorphous photovoltaic cell, while for the monocrystalline silicon, polycrystalline silicon and InGaP/InGaAS/Ge photovoltaic cells, the decrease proportion is much smaller (see the values for $\mathrm{TC}_{\mathrm{a}}(\mathrm{FF})$ from Table 1).

The series resistance and the ideality factor of diode are determined using the five-parameter method. The parameter can be determined with very good accuracy with the fiveparameter method, if the maximum power is determined 


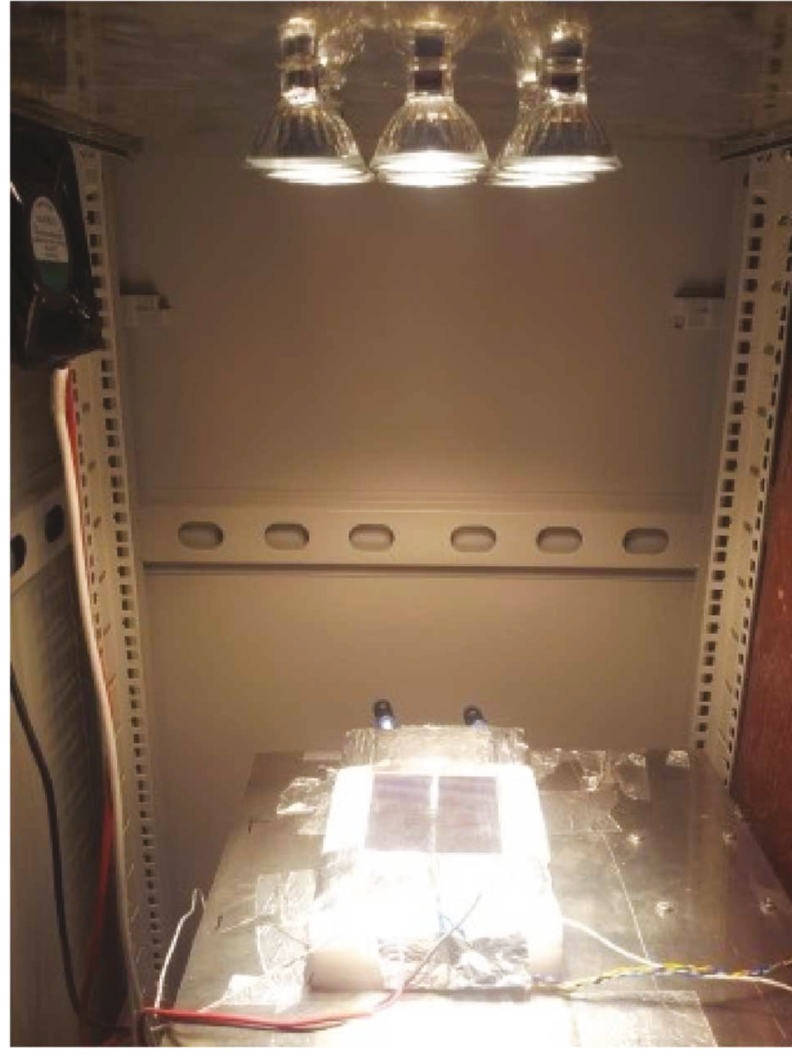

FIgURE 8: The laboratory experiment.

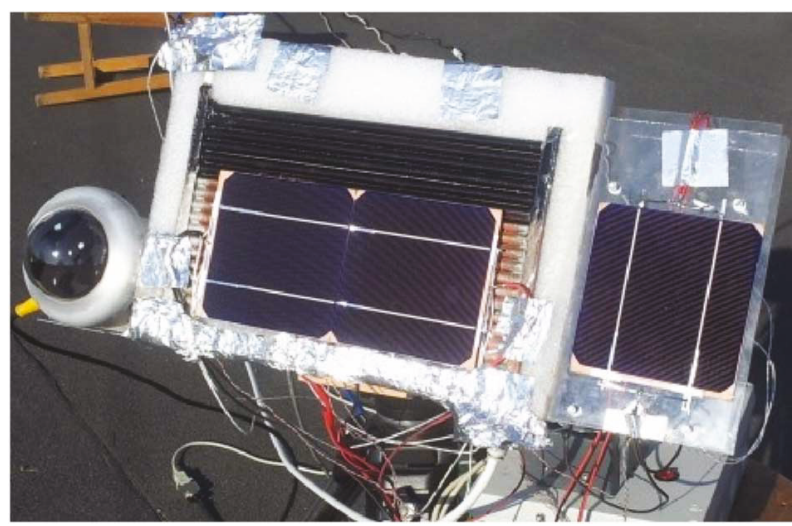

FIgURE 9: The natural sunlight experiment.

with very good accuracy [38]. The standard uncertainty of the module used to measure the $I-V$ characteristics is $0.016 \mathrm{mV}$, and the number of $I-V$ points is higher than 1000 , to minimize the errors in determining the maximum power.

The dependence of the series resistance for all photovoltaic cells on temperature at $1000 \mathrm{~W} / \mathrm{m}^{2}$ irradiance is presented in Figure 11(a). The series resistance decreases linearly with the increase in temperature. The series resistance is determined by the semiconductor resistivity and the resistance of the metal conductors. These two components depend on the temperature, first exponentially and then linearly. Figure 11(b) presents the variations of the ideality factor of all four photovoltaic cells with temperature at
TABLE 4: The calculated and measured values for $V_{\mathrm{oc}}$ and $I_{\mathrm{sc}}$ of $\mathrm{mSi}$ at $30^{\circ} \mathrm{C}$.

\begin{tabular}{llcccc}
\hline \multirow{2}{*}{ Laboratory } & & \multicolumn{2}{c}{$900 \mathrm{~W} / \mathrm{m}^{2}$} & \multicolumn{2}{c}{$1000 \mathrm{~W} / \mathrm{m}^{2}$} \\
& & $V_{\mathrm{oc}}(\mathrm{V})$ & $J_{\mathrm{sc}}(\mathrm{mA})$ & $V_{\mathrm{oc}}(\mathrm{V})$ & $J_{\mathrm{sc}}(\mathrm{mA})$ \\
\hline \multirow{3}{*}{ Sunlight } & Calculated & 0.5727 & 39.138 & 0.57482 & 43.487 \\
& Measured & 0.5719 & 39.08 & 0.574 & 43.422 \\
& Calculated & 0.5729 & 39.14 & 0.5748 & 43.486 \\
& Measured & 0.5704 & 39.04 & 0.5721 & 43.378 \\
\hline
\end{tabular}

TABle 5: The decreasing percent for $P_{\max }$ at $1000 \mathrm{~W} / \mathrm{m}^{2}$.

\begin{tabular}{lccccc}
\hline $\begin{array}{l}\text { The } \\
\text { photovoltaic cell }\end{array}$ & $\mathrm{mSi}$ & $\mathrm{pSi}$ & $\mathrm{aSi}$ & $\mathrm{InGaP} / \mathrm{InGaAs} / \mathrm{Ge}$ \\
\hline Percent $/{ }^{\circ} \mathrm{C}$ & $\mathrm{TI}$ & $-0.47 \%$ & $-0.38 \%$ & $-0.18 \%$ & $-0.14 \%$ \\
& {$[37]$} & $-0.45 \%$ & $-0.39 \%$ & $-0.23 \%$ & - \\
\hline
\end{tabular}

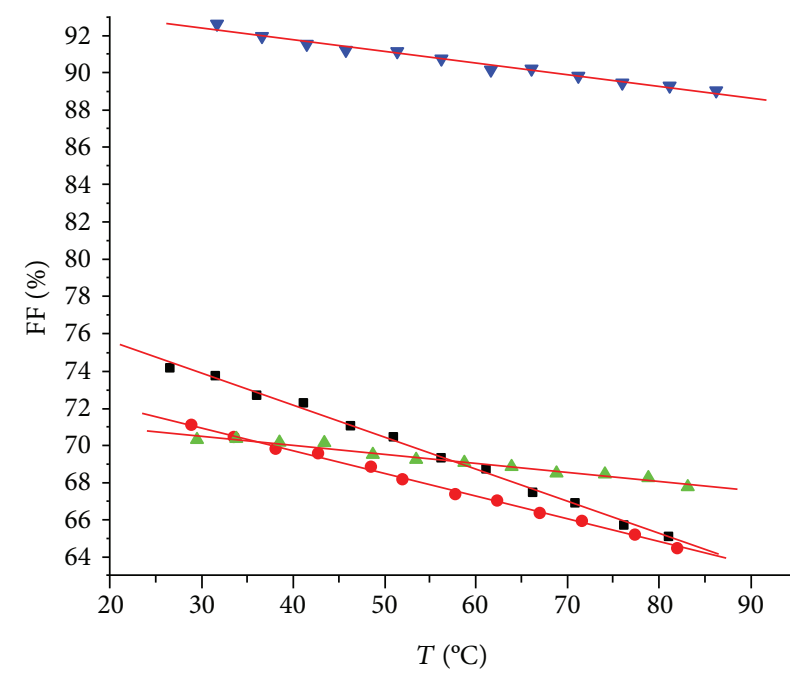

$$
\begin{array}{ll}
1000 \mathrm{~W} / \mathrm{m}^{2} & \\
\text { - } \mathrm{mSi} & \triangle \mathrm{aSi} \\
\text { - } \mathrm{pSi} & \nabla \mathrm{InGaP} / \text { InGaAs/Ge }
\end{array}
$$

FIGURE 10: The FF versus temperature at $1000 \mathrm{~W} / \mathrm{m}^{2}$ irradiance.

$1000 \mathrm{~W} / \mathrm{m}^{2}$ irradiance. A decrease in the ideality factor is observed with the increase in temperature. The ideality factor of diode $m$ decreases due to the decrease of the active layer resistance of the semiconductors or the temperature influence on surface recombination rate mechanism and Shockley-Read-Hall. The results obtained (Figure 11(c)) also indicate that the shunt resistance of all four photovoltaic cells decreases nearly linearly when the temperature of the cells increases. The $R_{\text {sh }}$ decreases because the shunt defects, as recombination centers or traps, and manufacturing defects increase with temperature growth. The decrease rate of the shunt resistance differs function of the type of the photovoltaic cells. The linear temperature dependence obtained for the three parameters of the photovoltaic cells is well consistent with ones found in literature $[14,39]$.

The values of the $\operatorname{TC}_{n}\left(I_{o}\right)$ were determined using (3), and the temperature coefficients $\mathrm{TC}_{\mathrm{a}}\left(V_{\mathrm{oc}}\right)$ and $\mathrm{TC}_{\mathrm{n}}\left(I_{\mathrm{sc}}\right)$ are presented in Table 6 . This method was verified using the values 

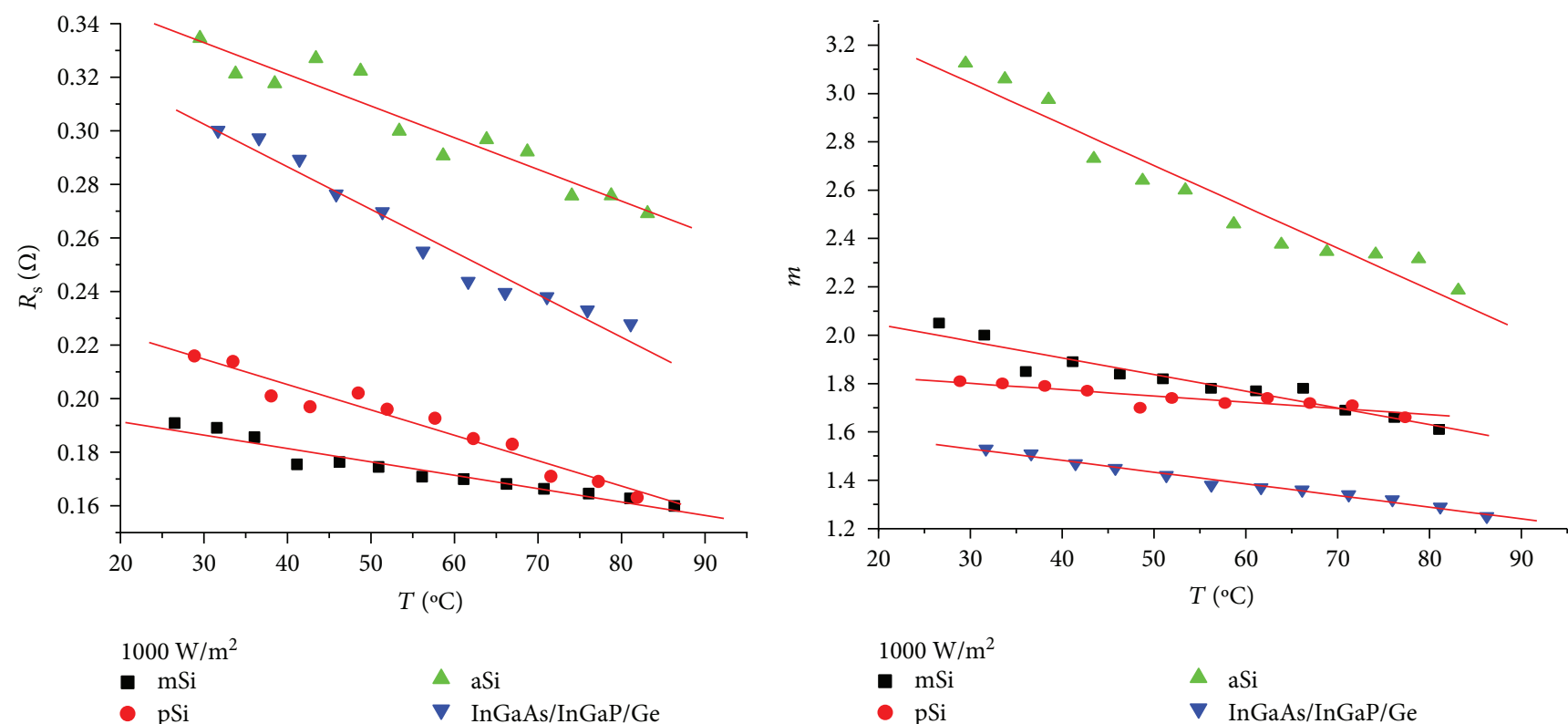

$1000 \mathrm{~W} / \mathrm{m}^{2}$

- $\mathrm{mSi}$

$\boldsymbol{\nabla} \mathrm{InGaAs} / \mathrm{InGaP} / \mathrm{Ge}$

- $\mathrm{mSi}$

$\nabla \mathrm{InGaAs} / \mathrm{InGaP} / \mathrm{Ge}$

(a)

(b)
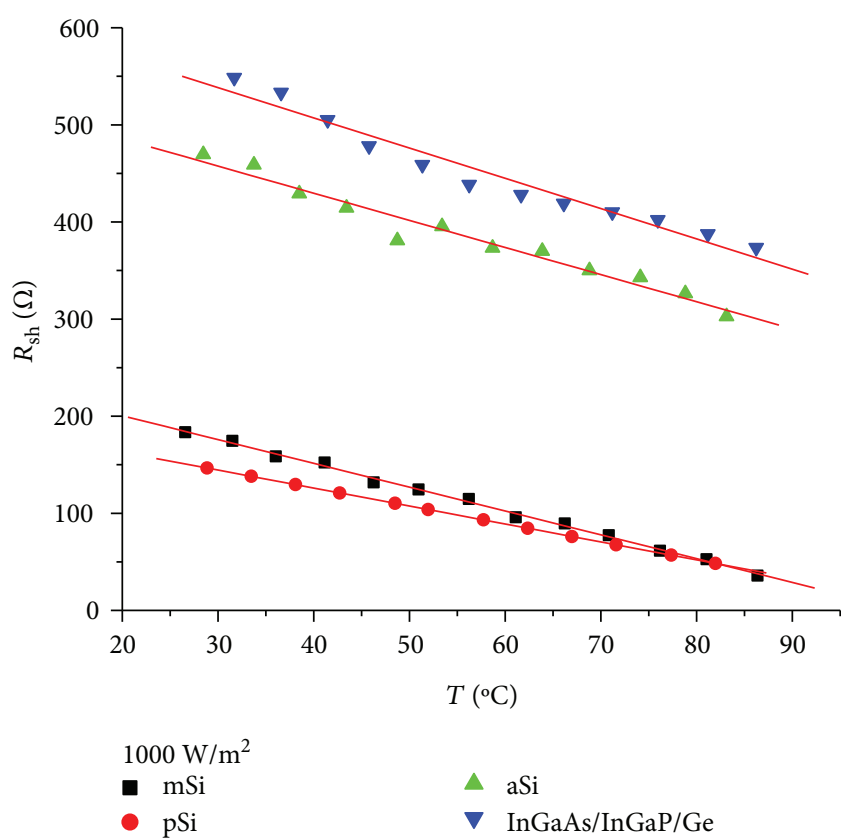

(c)

Figure 11: (a) The $R_{\mathrm{s}}$ versus temperature at $1000 \mathrm{~W} / \mathrm{m}^{2}$ irradiance (the values of the aSi $R_{\mathrm{s}}$ are divided with 30). (b) The $m$ versus temperature at $1000 \mathrm{~W} / \mathrm{m}^{2}$ irradiance. (c) The $R_{\mathrm{sh}}$ versus temperature at $1000 \mathrm{~W} / \mathrm{m}^{2}$ irradiance (the values of the aSi $R_{\mathrm{sh}}$ are divided with 30 and for multijunction with 40).

TABLE 6: The normalized temperature coefficient of the $I_{\mathrm{o}}$ at $1000 \mathrm{~W} / \mathrm{m}^{2}$.

\begin{tabular}{lccccc}
\hline $\begin{array}{l}\text { The photovoltaic } \\
\text { cell }\end{array}$ & $\mathrm{mSi}$ & $\mathrm{pSi}$ & $\mathrm{aSi}$ & $\mathrm{InGaP} / \mathrm{InGaAs} / \mathrm{Ge}$ \\
\hline$\left(d I_{\mathrm{o}} / d T\right) / I_{\mathrm{o}}$ & ${ }^{\circ} \mathrm{C}^{-1}$ & 0.164 & 0.161 & 0.636 & 0.591 \\
\hline
\end{tabular}

from reference [13]. The values calculated for the $\operatorname{TC}_{\mathrm{n}}\left(I_{\mathrm{o}}\right)$ for the three cases reported in [13] are $0.166 \mathrm{~K}^{-1}, 0.166 \mathrm{~K}^{-1}$, and $0.155 \mathrm{~K}^{-1}$ and using (3) are $0.170 \mathrm{~K}^{-1}, 0.170 \mathrm{~K}^{-1}$, and
$0.158 \mathrm{~K}^{-1}$. There are some differences due to the approximations made to obtain (3), but it is a very simple and rapid method to find out $\operatorname{TC}_{\mathrm{n}}\left(I_{\mathrm{o}}\right)$. The error in determining the normalized temperature coefficient of the $I_{0}$ is smaller than $3 \%$.

\section{Conclusions}

The performance of the four photovoltaic cells, $\mathrm{mSi}$, pSi, $\mathrm{aSi}$, and $\mathrm{InGaP} / \mathrm{InGaAs} / \mathrm{Ge}$, is analyzed depending upon 
the temperature and irradiance, by investigating the most important parameters, such as the open-circuit voltage, the short-circuit current, the maximum power, the series resistance, the diode's ideality factor, the reverse saturation current, and the fill factor. The photovoltaic cell temperature was varied from $25^{\circ} \mathrm{C}$ to $87^{\circ} \mathrm{C}$, and the irradiance was varied from $400 \mathrm{~W} / \mathrm{m}^{2}$ to $1000 \mathrm{~W} / \mathrm{m}^{2}$.

The temperature coefficients and their behavior in function of the irradiance of the enumerated parameters were calculated and compared with related literature results, and a good consistency is obtained. The analysis of the results underlines the fact that the temperature is an important factor which influences the performance of the photovoltaic cells. The maximum power decreases with values between $0.14 \%$ and $0.47 \%$ if the temperature increases with $1{ }^{\circ} \mathrm{C}$ for the photovoltaic cells analyzed.

The analysis shows that the absolute temperature coefficients of the parameters taken into consideration are dependent on the irradiance level. The irradiance has a small influence on the absolute temperature coefficient of the open-circuit voltage, but for the others, such as the absolute temperature coefficients of the short-circuit current and of the maximum power the influence, the irradiance is much higher. The variation of the last two absolute temperature coefficients with irradiance is almost proportional.

The improved models to predict the maximum power, short-circuit current, and the open-circuit voltage function of the temperature and irradiance are developed. A very simple and rapid way to calculate $\mathrm{TC}_{\mathrm{n}}\left(I_{\mathrm{o}}\right)$ is also described in this paper. The comparative results obtained for the open-circuit voltage, the short-circuit current measured, and the maximum power in different conditions, laboratory and outside, and the values calculated (estimated) with the temperature coefficients found, validate the improved models presented.

Consequently, in order to maximize the power generated by the photovoltaic cells, it is necessary to choose the optimum technology for the respective location, increasing the irradiance, for example, using the concentrated light and assuring a good cooling.

\section{Conflicts of Interest}

The authors declare that they have no conflicts of interest.

\section{Acknowledgments}

This work was supported by a grant of the Romanian National Authority for Scientific Research and Innovation, CNCS, UEFISCDI, Project no. PN-II-RU-TE-2014-4-1083 and Contract no. 135/1.10.2015.

\section{References}

[1] J. L. Sawin, F. Sverrisson, K. Seyboth et al., Renewables 2017 Global Status Report, REN21 Secretariat, Paris, France, 2017.

[2] G. M. Shafiullah, "Hybrid renewable energy integration (HREI) system for subtropical climate in Central Queensland,
Australia," Renewable Energy, vol. 96, Part A, pp. 1034-1053, 2016.

[3] X. Wang, N. H. El-Farra, and A. Palazoglu, "Optimal scheduling of demand responsive industrial production with hybrid renewable energy systems," Renewable Energy, vol. 100, pp. 53-64, 2017.

[4] A. Chel and G. Kaushik, "Renewable energy technologies for sustainable development of energy efficient building," Alexandria Engineering Journal, 2017, https://ac.els-cdn.com/ S1110016817300911/1-s2.0-S1110016817300911-main.pdf?_ tid=2de225ab-cefd-48f5-a087-7480a4cfe9f0\&acdnat $=$ 1520273225_372f323900114420e46ba92190113366.

[5] P.-P. Zhang, Z.-J. Zhou, D.-X. Kou, and S.-X. Wu, "Perovskite thin film solar cells based on inorganic hole conducting materials," International Journal of Photoenergy, vol. 2017, Article ID 6109092, 10 pages, 2017.

[6] A. Aissat, H. Arbouz, S. Nacer, F. Benyettou, and J. P. Vilcot, "Efficiency optimization of the structure pin-InGaN/GaN and quantum well-InGaN for solar cells," International Journal of Hydrogen Energy, vol. 41, no. 45, pp. 20867-20873, 2016.

[7] C. Zhang, J. Gwamuri, R. Andrews, and J. M. Pearce, "Design of multijunction photovoltaic cells optimized for varied atmospheric conditions," International Journal of Photoenergy, vol. 2014, Article ID 514962, 7 pages, 2014.

[8] A. E.-M. Aly and A. Nasr, "Theoretical study of oneintermediate band quantum dot solar cell," International Journal of Photoenergy, vol. 2014, Article ID 904104, 10 pages, 2014.

[9] S. Fara, P. Sterian, L. Fara, M. Iancu, and A. Sterian, "New results in optical modelling of quantum well solar cells," International Journal of Photoenergy, vol. 2012, Article ID 810801, 9 pages, 2012.

[10] D. T. Cotfas, P. A. Cotfas, and S. Kaplanis, "Methods to determine the dc parameters of solar cells: a critical review," Renewable and Sustainable Energy Reviews, vol. 28, pp. 588-596, 2013.

[11] S. Chander, A. Purohit, A. Sharma, Arvind, S. P. Nehra, and M. S. Dhaka, "A study on photovoltaic parameters of monocrystalline silicon solar cell with cell temperature," Energy Reports, vol. 1, pp. 104-109, 2015.

[12] O. Dupre, R. Vaillon, and M. A. Green, "Experimental assessment of temperature coefficient theories for silicon solar cells," IEEE Journal of Photovoltaics, vol. 6, no. 1, pp. 56-60, 2016.

[13] P. Singh and N. M. Ravindra, "Temperature dependence of solar cell performance-an analysis," Solar Energy Materials and Solar Cells, vol. 101, pp. 36-45, 2012.

[14] A. B. Or and J. Appelbaum, "Dependence of multi-junction solar cells parameters on concentration and temperature," Solar Energy Materials and Solar Cells, vol. 130, pp. 234-240, 2014.

[15] M. Benghanem, A. A. Al-Mashraqi, and K. O. Daffallah, "Performance of solar cells using thermoelectric module in hot sites," Renewable Energy, vol. 89, pp. 51-59, 2016.

[16] P. Singh, S. Singh, M. Lal, and M. Husain, "Temperature dependence of $I-V$ characteristics and performance parameters of silicon solar cell," Solar Energy Materials and Solar Cells, vol. 92, no. 12, pp. 1611-1616, 2008.

[17] D. J. Friedman, "Modelling of tandem cell temperature coefficients," in Conference Record of the Twenty Fifth IEEE Photovoltaic Specialists Conference - 1996, pp. 39-42, Washington, DC, USA, 1996. 
[18] K. Emery, J. Burdick, Y. Caiyem et al., "Temperature dependence of photovoltaic cells, modules and systems," in Conference Record of the Twenty Fifth IEEE Photovoltaic Specialists Conference - 1996, pp. 1275-1278, Washington, DC, USA, 1996.

[19] E. Radziemska, "The effect of temperature on the power drop in crystalline silicon solar cells," Renewable Energy, vol. 28, no. 1, pp. 1-12, 2003.

[20] M. Cui, N. Chen, X. Yang, and H. Zhang, "Fabrication and temperature dependence of a GaInP/GaAs/Ge tandem solar cell," Journal of Semiconductors, vol. 33, no. 2, article 024006, 2012.

[21] O. Dupré, R. Vaillon, and M. A. Green, "Physics of the temperature coefficients of solar cells," Solar Energy Materials and Solar Cells, vol. 140, pp. 92-100, 2015.

[22] Y. Riesen, M. Stuckelberger, F.-J. Haug, C. Ballif, and N. Wyrsch, "Temperature dependence of hydrogenated amorphous silicon solar cell performances," Journal of Applied Physics, vol. 119, no. 4, article 044505, 2016.

[23] D. T. Cotfas, P. A. Cotfas, D. Ursutiu, and C. Samoila, “The methods to determine the series resistance and the ideality factor of diode for solar cells-review," in 2012 13th International Conference on Optimization of Electrical and Electronic Equipment (OPTIM), pp. 966-972, Brasov, Romania, 2012.

[24] G. Segev, G. Mittelman, and A. Kribus, "Equivalent circuit models for triple-junction concentrator solar cells," Solar Energy Materials and Solar Cells, vol. 98, pp. 57-65, 2012.

[25] M. A. Green, "Solar cells-operating principles, technology and system applications," Solar Energy, vol. 28, no. 5, p. 447, 1982.

[26] M. A. Green, "Intrinsic concentration, effective densities of states, and effective mass in silicon," Journal of Applied Physics, vol. 67, no. 6, pp. 2944-2954, 1990.

[27] P. A. Cotfas and D. T. Cotfas, "Design and implementation of RELab system to study the solar and wind energy," Measurement, vol. 93, pp. 94-101, 2016.

[28] D. S. H. Chan, J. R. Phillips, and J. C. H. Phang, “A comparative study of extraction methods for solar cell model parameters," Solid-State Electronics, vol. 29, no. 3, pp. 329-337, 1986.

[29] C. R. Osterwald, T. Glatfelter, and J. Burdick, "Comparison of the temperature coefficients of the basic I-V parameters for various types of solar cells," in Conference Record of the Nineteenth IEEE Photovoltaic Specialists Conference-1987, pp. 188193, New Orleans, LA, USA, 1987.

[30] K. Nishioka, T. Takamoto, T. Agui, M. Kaneiwa, Y. Uraoka, and T. Fuyuki, "Annual output estimation of concentrator photovoltaic systems using high-efficiency InGaP/InGaAs/Ge triple-junction solar cells based on experimental solar cell's characteristics and field-test meteorological data," Solar Energy Materials and Solar Cells, vol. 90, no. 1, pp. 57-67, 2006.

[31] M. Tayyib, J. O. Odden, and T. O. Saetre, "Irradiance dependent temperature coefficients for MC solar cells from Elkem solar grade silicon in comparison with reference polysilicon," Energy Procedia, vol. 55, pp. 602-607, 2014.

[32] F. Mavromatakis, F. Vignola, and B. Marion, "Low irradiance losses of photovoltaic modules," Solar Energy, vol. 157, pp. 496-506, 2017.

[33] C. Morcillo-Herrera, F. Hernández-Sánchez, and M. FlotaBañuelos, "Method to calculate the electricity generated by a photovoltaic cell, based on its mathematical model simulations in MATLAB," International Journal of Photoenergy, vol. 2015, Article ID 545831, 12 pages, 2015.

[34] M. Fuentes, G. Nofuentes, J. Aguilera, D. L. Talavera, and M. Castro, "Application and validation of algebraic methods to predict the behaviour of crystalline silicon PV modules in Mediterranean climates," Solar Energy, vol. 81, no. 11, pp. 1396-1408, 2007.

[35] M. E. A. Slimani, M. Amirat, I. Kurucz, S. Bahria, A. Hamidat, and W. B. Chaouch, "A detailed thermal-electrical model of three photovoltaic/thermal (PV/T) hybrid air collectors and photovoltaic (PV) module: comparative study under Algiers climatic conditions," Energy Conversion and Management, vol. 133, pp. 458-476, 2017.

[36] E. Skoplaki and J. A. Palyvos, "On the temperature dependence of photovoltaic module electrical performance: a review of efficiency/power correlations," Solar Energy, vol. 83, no. 5, pp. 614-624, 2009.

[37] P. K. Dash and N. C. Gupta, "Effect of temperature on power output from different commercially available photovoltaic modules," International Journal of Engineering Research and Applications, vol. 5, no. 1, pp. 148-151, 2015.

[38] G. M. Tina and C. Ventura, "Evaluation and validation of an electrical model of photovoltaic module based on manufacturer measurement," in Sustainability in Energy and Buildings, pp. 15-24, Springer, Berlin, Heidelberg, 2012.

[39] E. Cuce, P. M. Cuce, and T. Bali, "An experimental analysis of illumination intensity and temperature dependency of photovoltaic cell parameters," Applied Energy, vol. 111, pp. 374$382,2013$. 

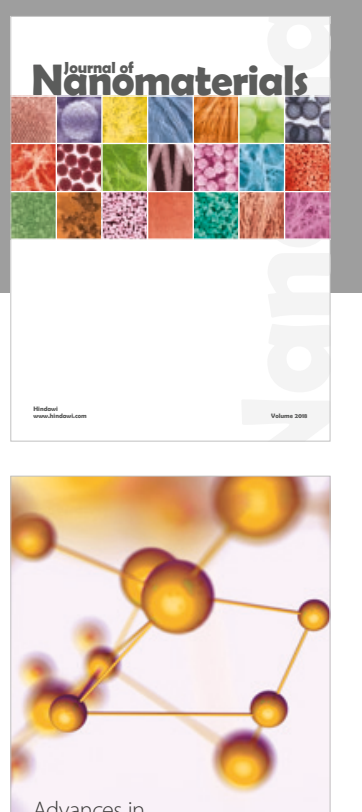

Physical Chemistry
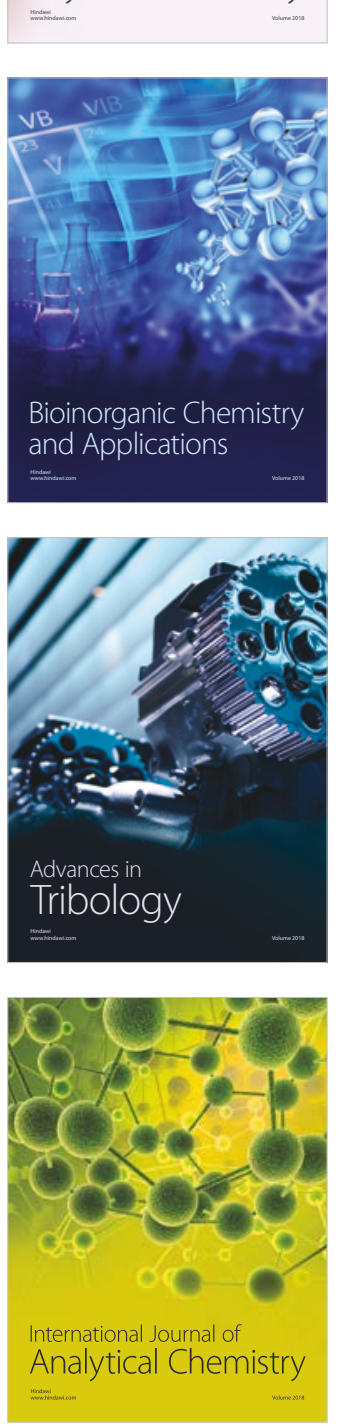

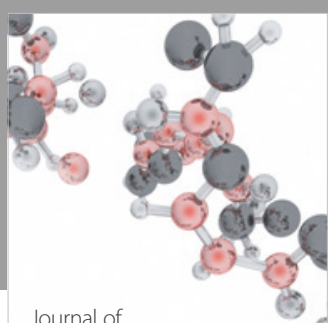

Analytical Methods

in Chemistry

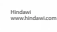

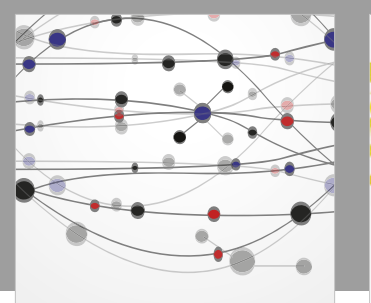

The Scientific World Journal

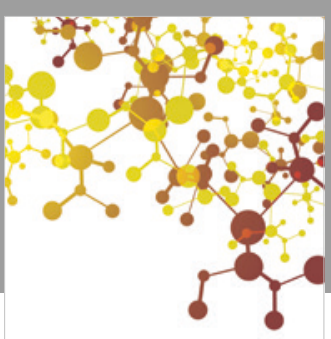

Journal of

Applied Chemistry
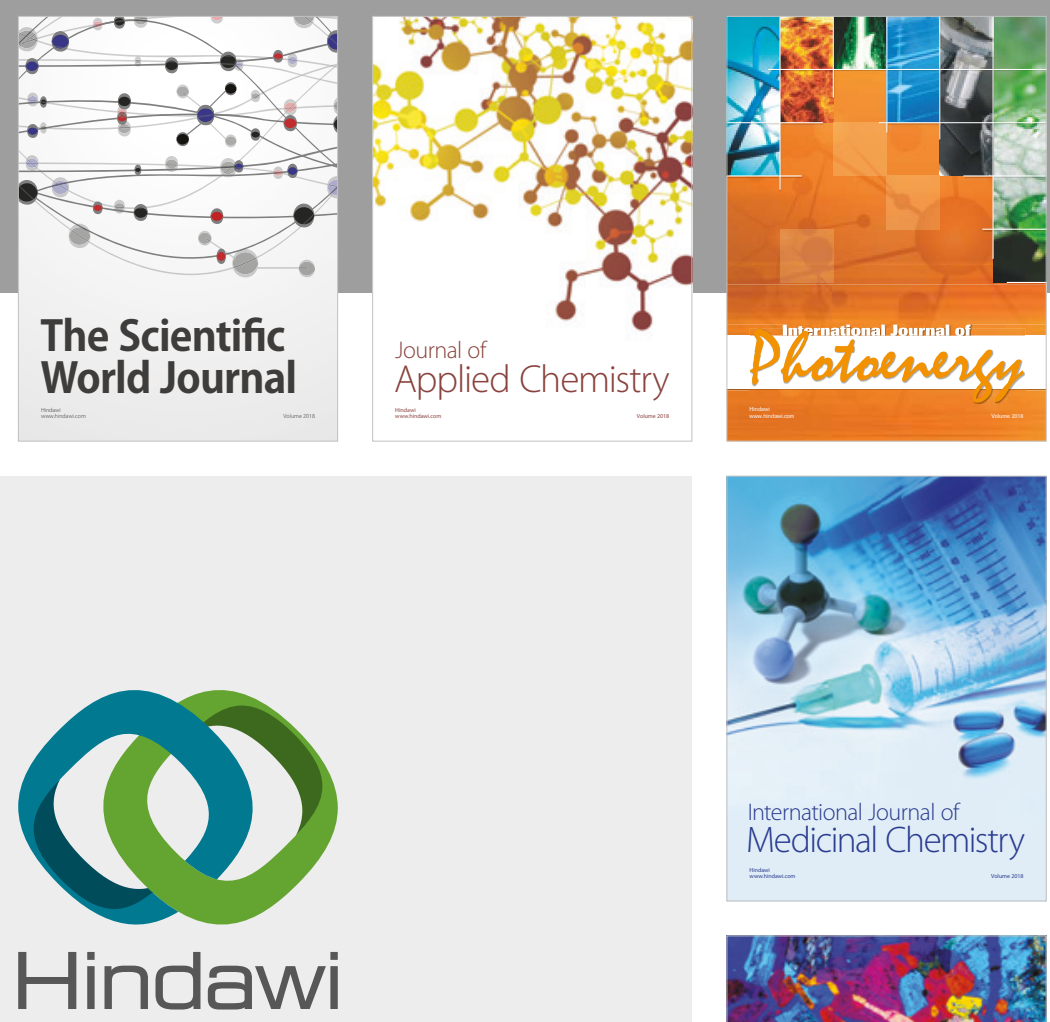

Submit your manuscripts at

www.hindawi.com
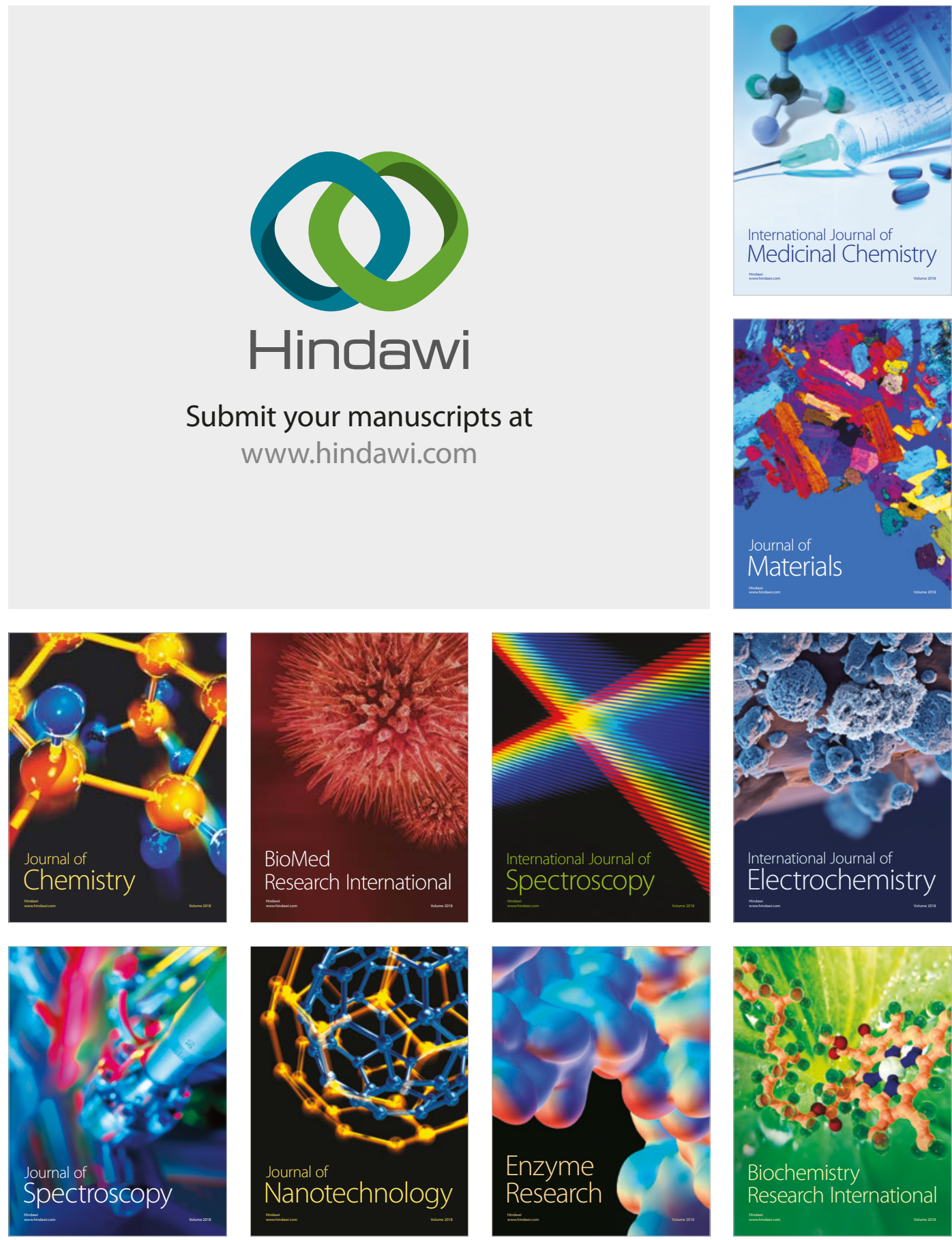
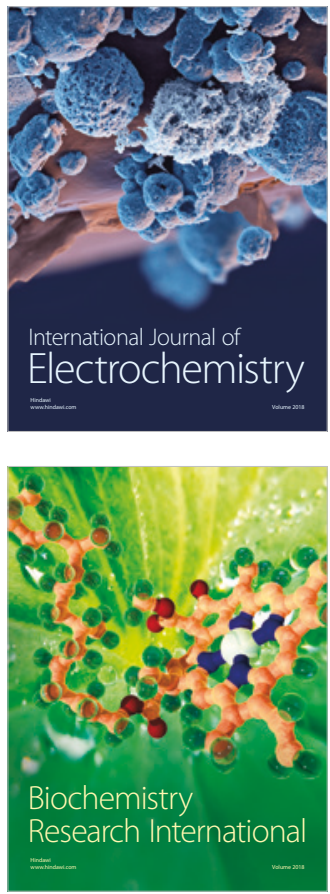